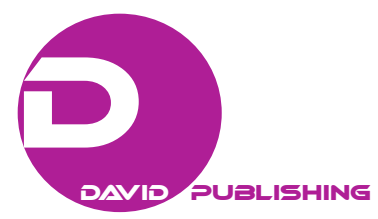

\title{
Peace and Human Rights: Communitarianism and the Limits to Liberal Peace
}

\author{
Lara Denise Góes da Costa \\ Brazilian War College, Rio, Brazil
}

\begin{abstract}
Peace can be understood as a pact for the perfection of institutions and through them the positivation of rights. In today's world, international wars and conflicts are marked by the cultural identities to which they relate, bringing to the fore historical social and humanitarian injustices. In this sense, it is possible to rethink peace studies via the communitarian perspective. Such a perspective points to social recognition for the appeal to human diversity, values being constructed according to each society or social group and not a priori with liberal presuppositions. In a society where rights exist for one group and not for another, the identity of the unrecognized group occurs through denial of rights. In addition to discrimination, non-realization of rights equally for all causes low-esteem and inhumanity obscuring social interaction that hinders recognition. In this context, this article defends what is expected as minority recognition is the possibility of self-affirmation as a group through the real participation of minority members in the majority group of equitable forms for the establishment of participatory governance of civil society in the effectiveness of peace.
\end{abstract}

Keywords: peace studies, human rights, social participation, civil governance

\section{Recognizing Peace as Human Right}

The course of peace and its theoretical articulation go from purely political authors to cosmopolitan moral philosophers, who in terms of international relations are considered utopian in their moral prescriptions at the states level. From Kant to the present day, there has been a great conceptual extension of what is understood as peace and how it should be reached. Some points, however, may be considered common to the debate. Firstly, the idea that regardless of the adoption of a realistic or idealistic perspective, thinking the war presumes an idea of peace. Secondly, peace or international security presupposes at least an agreement between the parties and states. From this agreement, the existence of alliances between states would be an efficient means to guarantee international security. Finally, it cannot be denied that there is an interest of states in ensuring global peace through ratification of international treaties on peace, human rights, and humanitarian affairs.

Currently, the United Nation (UN) General Assembly has developed a declaration of right to peace in July 2016, among which it states that:

Recognizing that peace is not only the absence of conflict, but also requires a positive and dynamic participatory process, where dialogue is encouraged and conflicts are resolved in a spirit of mutual understanding and cooperation, and the development of socio-economic character is ensured.

Lara Denise Góes da Costa, Ph.D. in Philosophy and Ph.D. in Social Sciences, assistant professor, Cordeiro de Farias Institute, Brazilian War College. 
And still,

Recognizing also the important contribution that civil society organizations can make to building and preserving peace and strengthening a culture of peace. Recalling that respect for diversity of cultures, tolerance, dialogue, and cooperation, in a climate of mutual trust and understanding, are among the best guarantees of international peace and security.

While some European Union (EU) countries have spoken out against this declaration, there is a move towards revising traditional views of peace only as an absence of armed conflict and extending it to cultural conceptions of non-discrimination, cultural tolerance, sustainable socio-economic development, and education for a culture of peace. As Ife (2007) had shown that peace cannot be achieved without human rights and this demands that the universality of human rights should be questioned from the importance of culture and not only from respect for international laws.

Although this argument can be considered relativistic, this theoretical debate is directed towards the historical insurgency of affirmation of cultural particularities that for centuries were neglected in the name of formal universalist statements that did not include alterity and concealed the ethnocentrism of theories that were called "neutral” or "unbiased". Such theories proceeded from the creation of a supranational structure as Habermas (2007) and Rawls (1993) pointed out, based in Kant. Determining an alliance among states understood as moral, in which the pact among them would be sufficient reason to guarantee a lasting or perpetual peace. From the 20th century, the democratic theories of peace that reinterpret the theory of perpetual peace Kantian understood the state as a participant in a global legal condition. Habermas (2007) pointed to the limits to behavior in war that were not contemplated in the Kantian theory, since the conflicts of great proportions did not exist in the 18thcentury. Moreover, Habermas (2007) showed that Kant did not explain how he would guarantee peace, but relied only on the rational-moral union among states.

\section{The Liberal Approach for Peace and its Critics}

In People's Law, Rawls (1993) created the ideal theory based on the fiction that in a society of people, actors are the people, as citizens in civil society. These actors would live under a just constitutional government and would be rational and reasonable, so they would not be in constant struggle for power or wealth since they would be economically reasonable. For Rawls, the more people acquire certain democratic characteristics, the more international stability is established at the global level. Peace, in this sense, would be guaranteed through respect for human rights, which would be a class of liberal fundamental rights. Its role would be to restrict only the reasons justifying the war. However, Rawls believed that a well-ordered people seek only just peace in war. No matter how utopian or idealistic the Rawlsian theory is, it has brought the bias of justice to the discussion of peace, adding to the studies of the area the hidden morality that underlies the political theories of peace.

Beitz, like Rawls, also combines historical and normative aspects that somehow transcend state boundaries. To the narrow conception, which concerns the global elements required by justice, elements that are considered as a particular category of reasons apply to the institutional structure of political and economic life. The question of global political justice is posed in a philosophical way-what is desirable from a global point of view-as well as an institutional one-which is possible from the point of view of the organization of institutions. Beitz is content to prescribe normative questions that should govern institutional actions. It concludes that institutions should recognize equal status of citizens and should provide individuals with the capacity to protect their interests against neglect or invasion of the state. Finally, like Habermas, it imposes that 
the institutions should establish a political environment that allows the informed citizens to deliberate on the political choices, forming a public arena of rational deliberation on the common good.

In contrast, critical international relations theorists like Linklater (2001) conceived the theme of peace from a cosmopolitan perspective and the moral potential of the relationship among human beings, believing in overcoming the nation-state from the emergence of global citizens via democratic structures. For Linklater (2001), the reasons for war are always trivial, and both the act of cooperating and the inhibiting role of public opinion are among the foundations of democratic peace.

We have seen that in the liberal sense of peace, moral and political construction goes hand in hand. However, they are articulated at the utopian, fictional, and prescriptive level, neglecting the reality of international society and the empirical content that characterizes it. With the assertion of liberalism in post-cold war European governments, the idea that democratic countries do not wage war against each other gained strength as a theoretical premise. The democratic theory of peace is based on the assumptions that leaders are controlled by the people as they participate in the decision-making processes of government actions, both domestic and international. Another important premise is that diplomacy and the use of international common institutions, as well as treaties and agreements made and ratified by countries, are an effective means of maintaining international security and peace. Another important starting point, this time via civil society, is the assumption that democratic peoples are more tolerant of other peoples and cultures, enabling more integration and reducing the cultural distance between them.

These premises function both as means for action among states as objectives that they aim to achieve for peacekeeping. However, we can see the insurgency of xenophobic, radical, and intolerant movements with immigrants and refugees that call into question important points of liberal peace, as well as the rhetorical use of the discourse of human rights guarantees as a means of violating the sovereignty of other states, economic interests (Chandler, 2003).

If, on the one hand, the division of international labor through economic globalization made possible a great integration among countries, insofar as it provides peace among them, as Mitrany (1990) stated, and in this sense the use of military force would be less useful under these conditions of interdependence, new types of conflicts or "new wars" (Kaldor, 1999) spread in different ways in the northern and southern hemispheres, the former being religious radicalization and terrorism as well as large contingents of refugees and immigrants also victims of local wars and conflicts, and in the southern hemisphere, drug trafficking and other transnational crimes, such as trafficking in arms and people, take part in the territories. These conflicts involve people, states, economies, and measures of international and domestic security, as well as influence the cultural perception we have of other peoples, cultures, and identities. Hence, the insurgency of nationalist movements that seek to "exclude" from their territories groups considered undesirable, such as immigrants and refugees who are considered "dangerous".

Until the end of the 19th century, manifestations of racism or in the current terms xenophobia, were related to the medical-legal knowledge of social control, in the form of elimination of those that did not correspond to the standard of health and security characteristic of European society (Foucault, 2006). The power of the European state, in general, aimed at the ability to hold the power of war, to be immune to a possible attack by other states or by populations considered "barbaric". European civilization perceived as barbarity any group or nation that did not possess its form of social organization, as well as the mechanisms of population discipline. 
In this context, this perspective led to the classification and separation of human beings, according to cultural differences - of which neither an ethnocentric view of the other was known or originated and the biological characteristics that would develop in a differentiated evolutionary scale at the same time that it connected them in the form of the successive continuity of the species. According to Foucault, new forms of social power are beginning to emerge, and the old class struggles are now redefined in strategies of force inside and outside the capitalist system, always having the European classification pattern of otherness.

In sum, we can say that although the theoretical construction of peace in liberal terms has been an important starting point for the maintenance of international security among nations, the premises from which they depart involve a detailed study of how we relate to cultural differences and with them are articulated in discursive terms. Thus, the universalistic formalism of liberal theories aims at the inclusion of all human beings regardless of race, culture, ethnicity, creed, etc., which in a certain way requires the articulation and cognoscibility of other cultures and social problems. In this sense, we turn to communitarian theory which, as a critique of liberal theories, points out solutions to the "empty individual” of moral liberalism.

\section{Diversity and Peace}

Galtung (1967) was perhaps the forerunner of new understandings of peace, both for his refusal of positivism in international relations theories, and for his quest for empirical grounding. As he realizes functional cooperation among groups or nations through technical and cultural cooperation or trade policies, Galtung (1967) uncovered the occult value agenda of liberal theoretical orthodoxy and thereby articulates a new triangulation between empiricism, criticism, and moral. Its division between positive peace as human integration and negative peace as absence of conflict aims to establish that theories of peace have an intimate connection with development theories, given the importance of investigating the past conditions on conflicts and the specific situation of structural violence of each nation in relation to the other. If there is a conflict, this means affirming that there is in some way an unequal distribution of power resources or market failures that lead to global poverty, socio-economic vulnerabilities, migratory flows, and the radicalization of oppressed groups, that is, new wars, but this time on a civil and global level. Although there is a heterogeneous set of individual, domestic, and systemic motivations and factors that overlap as an explanation for the occurrence of conflicts, the urgency of the collision of economic interests would be the major cause of war in the broad sense.

Cultural groups and societies have disparate values, which makes the universality of a whole made up of multiple diversities unfeasible. The followers of the liberal Rawlsian line argue that justice must be impartial and this requires a "neutral” or "above" conduct of particularities. From a communitarian point of view, social recognition takes place through the appeal to human diversity, the values being constructed according to each society or social group and not a priori with liberal presuppositions.

In a society where rights exist for one group rather than another, the identity of the unrecognized group occurs through denial of rights, as Nancy Fraser (2010) showed. In addition to discrimination, non-realization of rights equally for all causes low-esteem and inhumanity obscuring social interaction that hinders recognition. In this context, what is expected as a minority recognition is the possibility of self-affirmation as a group through the real participation of minority members in the majority group of equitable forms. This results in a status of paritative participation, so that its culture materializes and enables rights as a whole.

The so-called "communitarians" theorists specifically criticized some liberal authors, but also turned to some more general questions about liberalism. As a liberal neocontractualist theoretician, some communitarian 
critiques can be rescued from communitarians to think about the limits of liberalism, especially on Rawls's neocontractualist liberalism. In this sense, we will see some more comprehensive critiques of Macintyre (1991) and Taylor (2005) can be thought for the idea of impartiality of the veil of ignorance and in the broader sense of contractual perspective.

Macintyre (1991) would privilege the idea of history as a counterpoint to the "non-situated" perspective of the liberals. The historical perspective has become important not only as a science, but as an ally of moral philosophy (Dray, 1977) and some authors have been concerned with establishing a relationship between history and moral philosophy in contrast to theories considered more formal. The nature of this concern is for the purpose of discovering what the relevant actions were and events in a given period, but only to establish them, but to understand them, and this forces the historian-philosopher to provide explanations that show the relation between the event and the antecedent or synchronic conditions.

But social conditions are difficult to measure insofar as there is a need to relate the ontological dimension of institutions and the phenomena of the social world with all its system of rules, roles, relations, and symbols that express themselves under the form of events, thoughts and actions of collective behavior. This means that different ideas, ideologies, and mentalities in a culture can be generalized into concepts publicly affirmed, recorded, and shared as a single story.

Macintyre (1991) would be one of the philosophers who will criticize some exaggerations of the liberal theories. Among them, the claim of timeless truths in these theories in contradiction to the existence of “justice”, but not “justice”, universal, and impartial. The defense of impartiality for Macintyre comes about as a result of the European enlightenment, in which reason or rational inquiry is considered antithesis of the religious tradition, customs, and cultures of the various social orders. Defending that justice would be the foundation of social orders affirms that the preservation of order would be the goal of justice. However, it does not explain why order should be preserved. To arrive at the answer, we must first consider whether there is one or more of a basis for the existence of social rules, and it seems that the primary idea of the righteous can be considered as a foundation.

In contrast to Macintyre, Charles Taylor (2005) turned to the examination of the background, that is, the moral ontology that articulates our moral intuitions, the frames that give meaning and condition to our answers, what is and is not articulated and the foundation which we presuppose in terms of the worldview in common. Like Rawls, Taylor made a critique of modern utilitarianism, which argues that this is a secularized version of Christianity and in this quality is linked to a fundamental feature of Christian spirituality that has become central to modern culture. It is impossible for one to dispense with the configurations that provide the explicit or implicit foundation of our moral judgments. Living within these qualified horizons is constitutive of human action and in this sense identity is defined by the identifications and commitments that provide the structure in which the author can determine what is valuable, "I say that the horizons in which we live must include strong qualitative discriminations” (Taylor, 2009, p. 12).

Knowing who one is equivalent to being oriented in the moral space, a space in which questions arise about what is good or bad, what has importance and meaning for the individual and what is trivial and secondary? At the basis of this modern idea of identity is the notion that we do not solve things in universal terms and this is linked to our post-romantic understanding of individual differentiations as well as the importance we attach to the expression of each person's “discovery” of their moral horizon agreeing with Macintyre, part of Taylor's response is historical: Certain developments in our self-understanding are a 
precondition of our formulation of the question in terms of identity. To be able to answer for oneself is to know in which position one finds oneself, and in this sense, the notion of identity is related to the strong evaluation, that is, to the qualitative distinctions we make in life.

The idea of identity, in this sense, connects with the idea of a human community and of it to the interdependence as a culture of human rights, only that it is considered horizontally. Thus, by affirming the importance of the connection between particular historical narratives, identities, and a shared community idea, which together form a shared worldview of human rights, we are entering a possibility of establishing a shared peace idea, since the objectives human rights and peace are the same.

From the community level, we could then move on to the political level and from it to the global level, which when it returns to the individual, produces social and political effects again. Rosenau (2000) looked at transnational relations at the macro level of populations beyond that at the micro level of individuals. Realizing that transactions generate important effects and consequences for global issues, and the state's ability to control these effects has greatly diminished, which means the development of a profound transformation in both people's lives and the international system. For Rosenau (2000), global citizens have become important variables as there is a greater dispersion of the state and the emergence of global media and media, which in turn provoke new agendas and enable citizens in their community to see their contribution to the world.

\section{Conclusion}

In this way, addressing the issue of peace includes the discussion of identities and groups that are not protected by the human rights orbit via UN and democratic liberalism. Such protection, while extending to humanity as a whole, is not only effected by political discourse, but by the development of a culture of peace that means prevention and non-violent resolution of conflicts. For this to be possible, we must recognize the formal limits of normative liberalism to approach communitarianism as a strong and potential criticism for the recognition of human diversity.

\section{References}

Beitz, C. R. (2008). Cosmopolitanism and global justice. In Global ethics: Seminal essays. St. Paul, MN: Paragon House. Berdal, S. (2005). Crimen transnacional organizado y seguridade internacional. México, FCE: Cambio y continuidade.

Chandler, D. (2003). Rhetoric without responsibility: The attraction of "ethical” foreign policy. British Journal of Politics and International Relations, 5(3), 295-316.

Dray, W. (1977). Philosophy of history. Editions Zahar.

Foucault, M. (2006). Strategy, power-knowing, sayings and writings (Vol. 4). Rio de Janeiro: Forense Universitaria Editions. Fraser, N. (2001). Recognition without ethics. Journal Theory, Culture \& Society, 18, 21-42.

Galtung, J. (1967). Theories of peace: A synthetic approach to peace thinking. International Peace Research Institute. Habermas, J. (2007).The inclusion of others. Edition Loyola.

Ife, J. (2007). Humans rights and peace in Handbook of peace and conflict studies. Routledge.

Kaldor, M. (1999). New and old wars: Organized violence in a global era. Cambridge/Stanford: Polity Press/Stanford UP.

Kant, I. (2009). Perpetual peace. In Editions 70. Lisboa: Portugal.

Linklater, A. ( 2001). Citizenship, humanity, and cosmopolitan harm conventions. International Political Science Review, 22(3).

MacIntyre, A. (1991). Whose Justice? Which rationality? Notre Dame, Indiana: University of Notre Dame Press.

Magalhães, D. (2012). Conflict between theories of international relations on peace: Normative implications. International Relations Journal, 36.

Mitrany, D. (1990). Peace through cooperation and integration in BRAILLARD, Philippe. Theory of International Relations Editions Lisboa: Fundação Calouste Gulbenkian.

Pureza, J. M. (2001). The critical challenge of studies for peace. International Relations Journal, 36. 
Rawls, J. (1993). The law of peoples. Critical Inquiry, 20(1).

Rosenau, J. (2000). Governance without government: Order and transformation in world politics. UNB Editions.

Taylor, C. (2005). The recognition policy. Editions Gradiva.

Taylor, C. (2009). The ethics of autenticity. Editions 70.

Wendt, A. (1992). Anarchy is what states make of it: The social construction of power politics. Retrieved from http://www.ohchr.org/EN/HRBodies/HRC/RightPeace/Pages/WGDraftUNDeclarationontheRighttoPeace.aspx 